\title{
Chorioamnionitis at the Befelatanana university hospital centre of obstetric gynecology in Antananarivo Madagascar: epidemiology, taken care and forecast
}

\author{
Rakotonirina Martial ${ }^{1 *}$, Rainibarijaona L. N. A. ${ }^{1}$, Rakotozanany Besaina ${ }^{1}$, \\ Randriamahavonjy Romuald ${ }^{2}$, Tsifiregna R. L. ${ }^{3}$, Housni Ibrahim ${ }^{1}$, Hery Rakotovao A. ${ }^{1}$
}

\begin{abstract}
${ }^{1}$ Department of Gynecology Obstetrics, Befelatanana University Hospital Centre of Obstetric Gynecology in Antananarivo, Madagascar

${ }^{2}$ Department of Gynecology Obstetrics, Soavinandriana Hopital Center, Antananarivo, Madagascar

${ }^{3}$ Department of Pediatrics, Tanambao University Hospital Centre in Diego, Madagascar
\end{abstract}

Received: 29 October 2018

Revised: 05 June 2020

Accepted: 12 June 2020

\section{*Correspondence:}

Dr. Rakotonirina Martial,

E-mail: andriamarorakotonirina@gmail.com

Copyright: () the author(s), publisher and licensee Medip Academy. This is an open-access article distributed under the terms of the Creative Commons Attribution Non-Commercial License, which permits unrestricted non-commercial use, distribution, and reproduction in any medium, provided the original work is properly cited.

\begin{abstract}
Background: The chorioamnionitis corresponds to an infection of the ovular cavity. She puts game neonatal and maternal forecast. This study had as objectives to describe the epidemiological aspects, the taking care and the forecast of the chorioamnionitis to the gynecology teaching hospital and obstetrics Befelatanana, Madagascar.

Methods: It is about a descriptive, retrospective and transverse study, during a period of 6 months going from January, 2016 till July 2016. The pregnant women introducing a premature break of membranes (RPM) complicated with chorioamnionitis hospitalized in CHU-GOB during this period had been included.

Results: Authors found 35 cases of chorioamnionitis, that is $38.1 \%$ premature breaks of membranes. The medium age

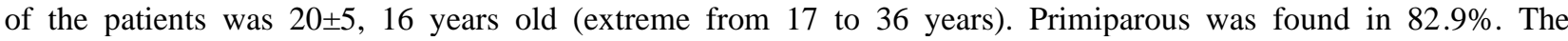
chorioamnionitis had happened in $68.5 \%$ cases after 37 weeks of amenorrhea. The delay between RPM and happened of chorioamnionitis was of 6 hours. The picture of chorioamnionitis was complete in 54.3\%. Delivery was by low way in $33.3 \%$. Authors had found $88.60 \%$ case of endometritis, $8.6 \%$ case of parietal suppuration post caesarian section but without any maternal decease. Neonatal complications were marked by a score of Apgar $<7$ - five minutes in $74.3 \%$, neonatal infection in $25.7 \%$ and precocious neonatal decease in $11.4 \%$.

Conclusions: The chorioamniotite concerned primiparous especially young urgent. The application of the protocol of taking care of the premature break of membranes is necessary for the reduction of the happening of the chorioamniotitis.
\end{abstract}

Keywords: Choriamniotitis, Forecast, Maternofetal infection, Premature break of membranes

\section{INTRODUCTION}

The chorioamnionitis defined as an infection contamination of the ovular bag. ${ }^{1}$ She often follows a premature break of membranes by pollution by ascending way. It is the most frequent pathology of the pregnancy, noticed in more half of very premature births (chorioamnionitis private hospitals and subclinical merged). ${ }^{2}$ In the developed countries, she is responsible for $12 \%$ perinatal mortality and of $9 \%$ precocious neonatal mortality. She can lead to a maternal hyperthermia in per-partum, to an endometritis of the 
postpartum and draw a bet away in job premature. ${ }^{3}$ In countries to weak-willed person with income, chorioamnionitis represents $18.2 \%$ of infections of perpartum. ${ }^{4}$

In Madagascar, the premature break of membranes constitutes $10 \%$ of admission of pathological pregnancy in study hospital to the teaching hospital GOB. The chorioamnionitis is not a rare complication, she is responsible for maternal and per natal morbidity in many worldwide studies but not enough data which approach this topic in Madagascar where from this study and that.

The forecast of the chorioamnionitis to the gynecology teaching hospital and obstetrics Befelatanana had as objectives to describe the epidemiological aspects, the taking care and the forecast of the chorioamnionitis to the gynecology teaching hospital and obstetrics Befelatanana, Madagascar.

\section{METHODS}

Authors led a transverse and preliminary descriptive retrospective study within the gynecology teaching hospital - obstetrics of Befelatanana, Madagascar. This hospital complex is a level III reference hospital located in the city centre of the capital, Antananarivo, Madagascar and which includes 6 services (service of obstetrical pathology, service of gynecological pathology, intensive care anesthesia - service - surgical unit, service imagery and biology, service of health of reproduction, a service of reception of the victims of sexual acts of violence, an administrative service). The delivery number in the study hospital was 8000 deliveries/year. Study took place over a period of 6 months going from January $1^{\text {st }}$, 2016 till July $31^{\text {st }}, 2016$. The population of study is constituted by the patients introducing a chorioamnionitis continuation in a break premature of membranes with a term the upper or equal to 28 week of amenorrhea (HER) taken care in the gynecology teaching hospital - obstetrics of Befelatanana during the period of study which answered this study criteria of inclusion. The diagnosis of the chorioamnionitis is established on diagnostic criteria of the national Secondary school of the gynecologists and obstetricians French (CNGOF) on 2009: a maternal fever $\left(>38^{\circ} \mathrm{C}\right)$ associate at least 2 signs as uterine sensitivity, contractile uterus, abnormal smell of the liquid amniotic the leukocytosis, fetal tachycardia (>160 bpm), (>15000 $\mathrm{GB} / \mathrm{mm}^{3}$ ) and maternal tachycardia (>100-120/min) ${ }^{5}$

All the others of reasons of fever during the pregnancy, a chorioamnionitis with undamaged membranes and the incomplete files were excluded from this study.

\section{Following variables were studied}

\section{Maternal variables}

Age (years), profession, conjugal situation, level d' education, gestate, parity, gestational age at the time of the diagnostic of the chorioamniotite (week amenorrhea $=$ HER), numbers clinical parameters of prenatal consultation in admission (weight, size, blood pressure, temperature, uterine fetal height and heart noise), biological parameters (NFS, CRP), time of clinical latency (delay between the premature beginning of membrane break and the happening of chorioamnionitis), maternal complications and hospitalization length

\section{For the newborn baby}

Born weight $(\mathrm{g})$, indication of Apgar in the $5^{\text {th }}$ minute, way of delivery and color of the liquid amniotic in birth.

\section{Statistical analysis}

Data were collected from the register of hospitalization of service and from the medical records of the patients and have analyzed summers has the assistant of software Ear - information version 3.2.2.

\section{RESULTS}

During the period of study, over 1927 admission in pregnancy service at risk we had recorded 35 cases of chorioamnionitis a prevalence of $1.81 \%$ of pathological pregnancy is. The medium age of the patients was $20 \pm 5$, 16 years old with extremes going from 17 to 36 years. The age group between 19 and 24 years represented $54.28 \%$ patients. Primiparous was the most affected (82.90\% patients). The gestational age of our patients was prematurely seen in almost $52 \%$ cases. The medium delay between break premature of membranes and the happening of the chorioamnionitis is of 6 hours with a minimum of 2 hours and a maximum of 74 hours. The picture of the chorioamnionitis was complete in $54.30 \%$ cases. The delay of latency less than 12 hours was the most represented proportion $(40 \%)$ (Table 1$)$.

Table 1: General characteristics of chorioamnionitis.

\begin{tabular}{|llll|}
\hline $\begin{array}{l}\text { Paramete } \\
\text { rs }\end{array}$ & Division & $\begin{array}{l}\text { Number } \\
(\mathbf{n = 3 5})\end{array}$ & $\begin{array}{l}\text { Rate } \\
(\%)\end{array}$ \\
\hline \multirow{3}{*}{$\begin{array}{l}\text { Age } \\
\text { Maternal } \\
\text { (year) }\end{array}$} & $<19$ & 5 & $14.2 \%$ \\
\cline { 2 - 4 } & $19-24$ & 19 & $54.2 \%$ \\
\cline { 2 - 4 } & $24-29$ & 7 & $20 \%$ \\
\cline { 2 - 4 } & $29-34$ & 2 & $5.7 \%$ \\
\hline \multirow{3}{*}{ Profession } & Housewife & 13 & $5.7 \%$ \\
\cline { 2 - 4 } & Primary sector & 11 & $31.1 \%$ \\
\cline { 2 - 4 } & Secondary sector & 9 & $25.7 \%$ \\
\cline { 2 - 4 } $\begin{array}{l}\text { Conjugal } \\
\text { situation }\end{array}$ & Tertiary sector & 2 & $5.7 \%$ \\
\hline \multirow{3}{*}{$\begin{array}{l}\text { Education } \\
\text { level }\end{array}$} & Single & 32 & $91.4 \%$ \\
\cline { 2 - 4 } & Illiterate & 3 & $8.5 \%$ \\
\cline { 2 - 4 } & Primary & 1 & $2.8 \%$ \\
\cline { 2 - 4 } & Secondary & 13 & $40.0 \%$ \\
\hline
\end{tabular}




\begin{tabular}{|c|c|c|c|}
\hline $\begin{array}{l}\text { Paramete } \\
\text { rs }\end{array}$ & Division & $\begin{array}{l}\text { Number } \\
(n=35)\end{array}$ & $\begin{array}{l}\text { Rate } \\
(\%)\end{array}$ \\
\hline \multirow{3}{*}{ Parity } & Primiparous & 29 & $82.9 \%$ \\
\hline & Multiparous & 4 & $11.4 \%$ \\
\hline & Great multiparous & 2 & $5.7 \%$ \\
\hline \multirow{3}{*}{$\begin{array}{l}\text { Gestationa } \\
1 \text { age }\end{array}$} & $28-34$ & 3 & $8.5 \%$ \\
\hline & $34-37$ & 8 & $22.8 \%$ \\
\hline & $\geq 37$ & 24 & $68.5 \%$ \\
\hline \multirow{4}{*}{$\begin{array}{l}\text { Time of cli } \\
\text { nical laten } \\
\text { cy (hour) }\end{array}$} & $<12$ & 14 & $40 \%$ \\
\hline & $12-24$ & 13 & $37.1 \%$ \\
\hline & $24-48$ & 7 & $20 \%$ \\
\hline & $\geq 48$ & 1 & $2.9 \%$ \\
\hline \multirow{3}{*}{$\begin{array}{l}\text { Chorioamn } \\
\text { ionitis tabl } \\
\text { es }\end{array}$} & Fever +2 signs & 4 & $11.4 \%$ \\
\hline & Fever +3 signs & 12 & $34.3 \%$ \\
\hline & $\geq 4$ signs & 19 & $54.3 \%$ \\
\hline \multirow{3}{*}{$\begin{array}{l}\text { Born weight } \\
\text { (g) }\end{array}$} & $<1500$ & 1 & $2.8 \%$ \\
\hline & $1500-2500$ & 8 & $22.8 \%$ \\
\hline & $\geq 2500$ & 26 & $74.2 \%$ \\
\hline \multirow{2}{*}{$\begin{array}{l}\text { White cell } \\
\left(\mathrm{GB} / \mathrm{mm}^{3}\right)\end{array}$} & $>15000$ & 29 & $82.8 \%$ \\
\hline & $<15000)$ & 7 & $20 \%$ \\
\hline \multirow{3}{*}{ CRP (mg/L) } & $<50$ & 6 & $17.1 \%$ \\
\hline & $50-100$ & 15 & $42.8 \%$ \\
\hline & $\geq 100$ & 14 & $40 \%$ \\
\hline
\end{tabular}

Table 2: Forcast and Maternofetal complications.

\begin{tabular}{|llll|}
\hline Parameters & Division & $\begin{array}{l}\text { Number } \\
(\mathbf{n = 3 5})\end{array}$ & $\begin{array}{l}\text { Rate } \\
(\%)\end{array}$ \\
\hline $\begin{array}{l}\text { Way of } \\
\text { delivery }\end{array}$ & Caesarean & 23 & $56.7 \%$ \\
\cline { 2 - 4 } Medical & Low way & 12 & $33.3 \%$ \\
\hline treatment & Antibiotic therapy & 35 & $100 \%$ \\
\cline { 2 - 4 } & Tocolysis & 3 & $8.5 \%$ \\
\hline \multirow{2}{*}{$\begin{array}{l}\text { Maternal } \\
\text { complication }\end{array}$} & Antipyretic & 18 & $51.4 \%$ \\
\cline { 2 - 4 } & Endometritis & 31 & $88.5 \%$ \\
\cline { 2 - 4 } Neonatal & Maternal death & 0 & $11.4 \%$ \\
\cline { 2 - 4 } complication & Apgar $<7$ & 26 & $74.3 \%$ \\
\cline { 2 - 4 } & Neonatal infection & 9 & $25.7 \%$ \\
\cline { 2 - 4 } & Neonatal death & 4 & $11.4 \%$ \\
\hline
\end{tabular}

*Infection of the operative site.

Among 35 women included in this study, 23 women gave birth by caesarean section. The neonatal asphyxia was fetal complication the most frequent followed by precocious neonatal infection and by the decease. As regards maternal forecast, the endometritis was the most frequent maternal complication is $88.60 \%$ cases coherent of an infection of the surgical site and no decease nursery school (Table 2) was objectified.

\section{DISCUSSION}

In this study, the frequency of chorioamnionitis found in this series is more important (38.01\% RPM). In Morocco in 2017, he brought back Units States 8.3\% urgent RPM. ${ }^{6}$ Aux from 1988 till 2005, Laibl and his collaborators found $10 \% .^{7}$ Authors found a prevalence then raised in comparison with Africain series and in the developed countries. It could explain of one due to the fact that CHUGOB is a hospital complex public. It's a reference centre, receiving cases obstetrical is complicated in Antananarivo city and all its peripheries. Also risk factors of chorioamnionitis are more important because it is a country under press with a social and economic low level. Finally, criteria used to put down diagnosis differ.

The mean of age of our patients was $20 \pm 5,16$ years old. In Africa a study led to Morocco by Asmama $\mathrm{Y}$ and its collaborators found a medium age of 28 ans. ${ }^{6}$ In France, the medium age found. The population was 33 ans. ${ }^{8}$ Am therefore young that in Africa and that in the Western countries and meets.

Primiparous was the most concerned by the chorioamnionitis with predominance almost $83 \%$ in this study. In Africa Asmama Y and his collaborators found that multiparous predominates $(51.4 \%) .^{6}$ In France, Ronzino also brought back a predominance to multiparous (81\%). ${ }^{8}$ This difference was owed that the Malagasy primiparous is not concerned about their pregnancies.

Concerning length latency that is length between RPM and happening of the chorioamnionitis. In this series, the medium time of latency was of 6 hours. This joins of that found in Africa (6 hours) 9 and in France (7 hours). ${ }^{8}$

The gestational age of our patients was prematurely seen in almost $52 \%$ cases. In literature, the frequency of amniotic infections diagnosed after amniocentesis is very high in RPM prematurely: from $15 \%$ to $57 \%$ (35\% on average). ${ }^{10,11}$

For the elements of diagnostic private hospitals, the picture of chorioamnionitis was complete in 54.30\%. In France, Paumier A brought back a complete picture in $36.6 \%$ of cas. $^{12}$

In this series of study, caesarian section was found dan $56.7 \%$ against delivery by low way $(33.3 \%)$. The delivery way by caesarian section is comparable to that noticed in Africa by Ramsey PS (72.2\%) and in France by RonzinoDubost (54\%). ${ }^{6,8}$ Caesarian sections had been therefore the way of delivery most solicited in very studies this fact to explain that objective it is fetal extraction immediately for rescue fetal but ca job depends on the degree of progress.

Concerning maternal forecast, the endometritis was the most frequent maternal complication is $88.60 \%$ cases coherent of an infection of the surgical site $(8.60 \%)$ and no decease nursery school in 6 months was objectified. This corobore with the results of Saizonou $\mathbf{J}$ et al in Benin where the endometritis $(27.3 \%)$ was the most accused type of infection. In study multicenter dirty, the upper rate of impact of endometritis of 50\% was found and she was 3-4 times as frequent after caesarian section 
as after delivery by way basse. ${ }^{13-14}$ In the world, the maternal morbidity by an endometritis, the bacteremia, the sepsis and the infection of the surgical site is important. Maternal mortality is raised in Western Africa 15 and a weak impact in the European countries: 2-5 cases/year. ${ }^{16}$ The results of our series seem therefore encouraging. Letting think that the taking care immediately from chorioamnionitis spares the mothers of strict complication found in literature.

For fetal forecast, the neonatal asphyxia was the most frequent fetal complication $(74.30 \%)$ monitoring of the precocious neonatal infection $(25.70 \%)$ and of the decease (11.40\%). In the Africans series, they found: neonatal decease $(3.6 \%)$, asphyxia neonatal $(11.5 \%)$ and European: neonatal decease $(9 \%)$, asphyxia neonatal $(8 \%)$ and the neonatal infection $(36 \%){ }^{8,17}$ In Africa and in Europe, he had brought back a neonatal death rate and asphyxia widely inferior to that found in this study. This difference could explain by the difference of a technical set.

\section{CONCLUSION}

The choriomnionitis is a source of strict neonatal and maternal morbidity. She concerned primiparous especially young urgent. The borders of our study are a retrospective and descriptive study with a weak sampling. Prevention is primordial as the application of the protocol of taking care of the premature break of membranes, the screening of the cervical and vaginal infections, the application of the protocols of antibiotic prophylaxis and of the antibiotic therapy in the course of the pregnancy.

\section{Funding: No funding sources}

Conflict of interest: None declared

Ethical approval: Not required

\section{REFERENCES}

1. Redline RW. Inflammatory response in acute chorioamnionitis. Sem Fetal Neonat Med. 2012;17:205.

2. Redline RW. Placental inflammation. Sem Neonat 2004;9:265-74.

3. Gravett MG, Novy MJ, Rosenfeld RG, Reddy AP, Jacob T, Turner M, et al. Diagnosis of intra-amniotic infection by proteomic profiling and identification of novel biomarkers. JAMA. 2004;292:462-9.

4. Saizonou J, Ouédraogo L, Paraiso MN, Ayélo P, Kpozèhouen A, Daraté R, et al. Epidemiology and management of intrapartum infections in the maternity ward of Ouémé-Plateau county hospital in Benin. The Pan African Med J. 2014;17:89.

5. Beucher G, Charlier C, Cazanave C. Diagnosis and management of intra-uterine infection: CNGOF preterm premature rupture of membranes guidelines. Gynecol Obstet Fertil Senol. 2018;46(12):1054-67.

6. Yasmina A, Barakat A. Prelabour rupture of membranes (PROM) at term: prognostic factors and neonatal consequences. The Pan African Med J. 2017;26:68.

7. Laibl V, Sheffield J, Roberts S. Recurrence of clinical chorioamnionitis in subsequent pregnancies. Obstet Gynecol. 2006;108:1493-67.

8. Ronzino-Dubost V, Sananès N, Lavaux T, Youssef C, Gaudineau A, Lecointre L, et al. Evaluation of the interest of procalcitonin in the diagnosis of chorioamnionitis in preterm premature rupture of membranes. An observational and prospective study. J Gynecol Obstet Bio Reprod. 2016;45(7):745-53.

9. Horo A, Toure'-Ecra F, Mohamed F, Koné M. Malfunction and mortality kindergarten. Analysis of 35 cases at the maternity hospital of Yopougon University Hospital (Abidjan Côte d'Ivoire). Med Afr Noire. 2008;55(8):44-53.

10. Berardi JC, Colaou JC, Engelmann P, Botto JN, Vice P, Robichez B. Study of the bacterial colonization of the amniotic fluid collected by amniocentesis in the event of premature rupture of the membranes. J Gynecol Obstet Biol Reprod. 1995;24:69-73.

11. Gomez R, Romero R, Edwin SS, David C. Pathogenesis of preterm labor and preterm premature rupture of membranes associated with intraamniotic infection. Infect Dis Clin North Am. 1997;11(1):135-76.

12. Allen SR. Epidemiology of premature rupture of the fetal membranes. Clin Obst Gynecol. 191;34:685-93.

13. French JI, Mc Gregor JA. The pathobiology of premature rupture of membranes. Curr Opin Obstet Gynecol. 1995;7:140-5.

14. Paumier A. Rupture premature des membranes avant 32 semaines amenorrhea: factors prostitute prenatal. Gynecol Osterie Fertil. 2008;36:748-56.

15. Grether JK. Maternal infection and cerebral palsy in infants of normal birth weight. JAMA. 1997;278:20711.

16. Lamy CS, Zuily E, Perdriolle E, Gauchotte S, Villeroyde-Galhau MO, Delaporte D, et al. Management of post-partum infections. J Gyne Obstet Bio Reprod. 2012;41:886-903

17. Jacques S, Laurent Ô, Moussiliou NP, Paul A, Alphonse K, René D, et al. Epidemiology and management of per-partum infections at the maternity ward of the Ouémé Plateau Hospital in Benin. Pan Afr Med J. 2014; 17:82.

Cite this article as: Martial R, Rainibarijaona LNA, Besaina R, Romuald R, Tsifiregna RL, Ibrahim H, et al. Chorioamnionitis at the Befelatanana university hospital centre of obstetric gynecology in

Antananarivo Madagascar: epidemiology, taken care and forecast. Int J Reprod Contracept Obstet Gynecol 2020;9:2778-81. 